\title{
378. 胃部造影画像分類の再検討と新開発高濃度バリウムの臨床評価
}

Review of Classification of Barium Coating in Upper Gl

with High Density Barium Suspension.

慶応義熟大学病院

東京医大霞ヶ浦病院

\section{○都築 史郎 S. Tuzuki} 海老根精二
佐藤 忠

T. Satou

千葉県がんセンター
永茾義衛
【目的】これまで，胃X楾造影用バリウム評洒で，胃小 区描出率・付着性・”べたつき”などが，検討項目に上げ られて来た。しかし，第19回総会学術大会で佐藤等が発表 した胃部造影画像分類法の中で「バリウム造影剂評洒は同 じ分類で比較するか，できれば同一被検者の画像で行う必 要がある」とし，これまでの胃小区描出率・付着性・べた つきでのバリウム評洒法は, 正しい方法ではないと主張し た。この主張は, “新しいバリウム評価の観点”であると 考えこの分類法存再検討し，同時に新たに開発された高濃 度バリウムの臨床評価を行ったので報告する。

【方法】1. 被検者62例の前回と今回の背卧位二重造影 像を分類し，同一被検者同一分類出現率を算出した。

2、高濃度バリウムを使用し，従来のバリウムと比較した。 【結果】1.同一被検者同一分類出現率は92\%であった。 同一分類にならなかった 5 例中 4 例はバリウムの付着・特 性の違いによるもので，質的には同一分類と考えられる。 被検者の胃粘膜にはバリウムで胃小区や病変が良く示顕さ れるものと，バリウムが粘液状となり描出されないものが あり，被検者の胃固有のものと考えられる。2，同一被検 者による前回画像之の比較では，高濃度バリウムが $66 \%$ と 画像評価が高く，胃粘膜示顕能が優れている。

【考察】1, 同一被検者同一分類出現率92\%は，この分 類法の正しさを示し，“新し いバリウム評価の観点”であ ることを示している。2，こ の分類法を用いての画像評価 では，良・悪の評価の対立は $21 \%$ でこれまでの胃小区描出 率・べたつき・付着性を異な った分類により行われた評価 より精度の高い画像評価にな ったように思われる。

\begin{tabular}{|c|r|r|}
\hline \multicolumn{3}{|c|}{ 同一パターン出現率 } \\
\hline パターン & 症例|出現率 \\
\hline A & 8 & $13 \%$ \\
\hline B & 16 & $26 \%$ \\
\hline C & 21 & $34 \%$ \\
\hline D & 4 & $6 \%$ \\
\hline F & 6 & $10 \%$ \\
\hline 同一パターン & 2 & $3 \%$ \\
\hline 韭同ーパターン & 5 & $92 \%$ \\
\hline
\end{tabular}

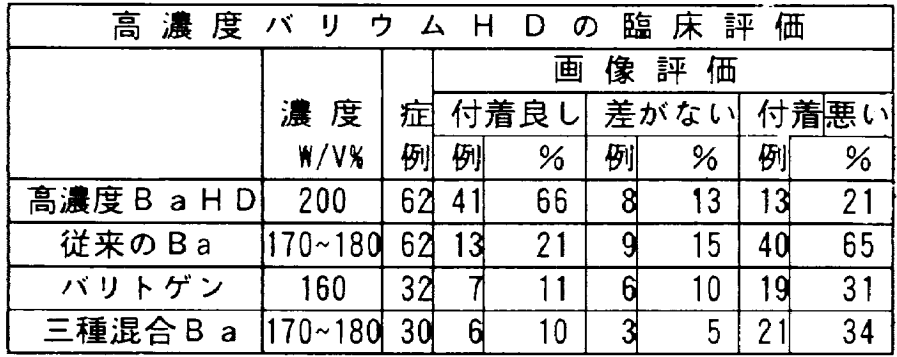

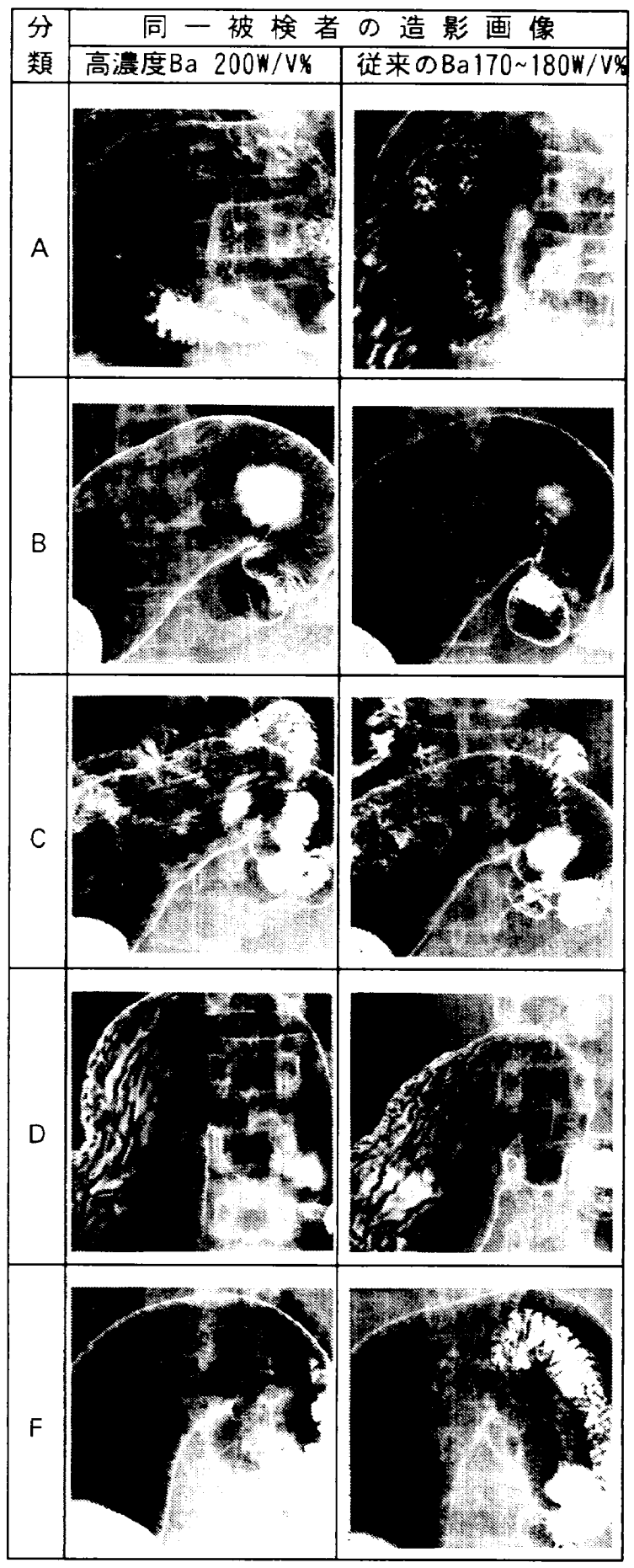

